\title{
Communication
}

\section{New Antioxidative Secondary Metabolites from the Fruits of a Beibu Gulf Mangrove, Avicennia marina}

\section{Cheng-Hai Gao ${ }^{1}$, Xiang-Xi Yi ${ }^{2}$, Wen-Pei Xie ${ }^{1,2}$, Yin-Ning Chen ${ }^{3}$, Ming-Ben Xu ${ }^{1}$, Zhi-Wei Su ${ }^{1}$, Lian Yu ${ }^{1}$ and Ri-Ming Huang ${ }^{3,4, *}$}

1 Guangxi Key Laboratory of Marine Environmental Science, Guangxi Academy of Sciences, Nanning 530007, China; E-Mails: gaochenghai@gxas.cn (C.-H.G.); xwpei-028@163.com (W.-P.X.); xmben0771@126.com (M.-B.X.); suzw1454@126.com (Z.-W.S.); lianyu@gxu.edu.cn (Y.L.)

2 School of Pharmaceutical Sciences, Guangxi University of Chinese Medicine, Nanning 530001, China; E-Mail: xiangxiyi81@aliyun.com

3 Key Laboratory of Plant Resources Conservation and Sustainable Utilization, South China Botanical Garden, Chinese Academy of Sciences, Guangzhou 510650, China; E-Mail: chendianyu3356@163.com

4 Department of Pharmacy and Pharmacology, University of Bath, Bath BA2 7AY, UK

* Author to whom correspondence should be addressed; E-Mail: huangriming@scib.ac.cn; Tel./Fax: +86-20-3525-2958.

Received: 28 May 2014; in revised form: 2 July 2014 / Accepted: 17 July 2014 /

Published: 29 July 2014

\begin{abstract}
Further chemical investigation of the fruits of the mangrove, Avicennia marina, afforded three new phenylethyl glycosides, marinoids J-L (1-3), and a new cinnamoyl glycoside, marinoid M (4). The structures of isolates were elucidated on the basis of extensive spectroscopic analysis and by comparison of the data with those of related secondary metabolites. The antioxidant activity of the isolates was evaluated using the cellular antioxidant assay (CAA), and compounds 1-4 showed antioxidant activities, with $\mathrm{EC}_{50}$ values ranging from $23.0 \pm 0.71 \mu \mathrm{M}$ to $247.8 \pm 2.47 \mu \mathrm{M}$.
\end{abstract}

Keywords: antioxidant; Avicennia marina; caffeoyl glycoside; marinoid; phenylethyl glycoside 


\section{Introduction}

During the course of our search for new bioactive secondary metabolites from the mangrove, Avicennia marina (Forsk.) Vierh. (Acanthaceae family), some jacaranone analogs, marinoids F-I [1], have been obtained. Because of our interest in searching for new bioactive natural products, the continuing investigation on the chemical constituents of the fruits of this specimen was carried out and resulted in the isolation of three new phenylethyl glycosides, marinoids $\mathrm{J}-\mathrm{L}$ (1-3), and a new cinnamoyl glycoside, marinoid M (4) (Figure 1). This paper deals with the isolation, structural elucidation and antioxidant activity of these secondary metabolites.

Figure 1. Secondary metabolites $\mathbf{1}-\mathbf{4}$.

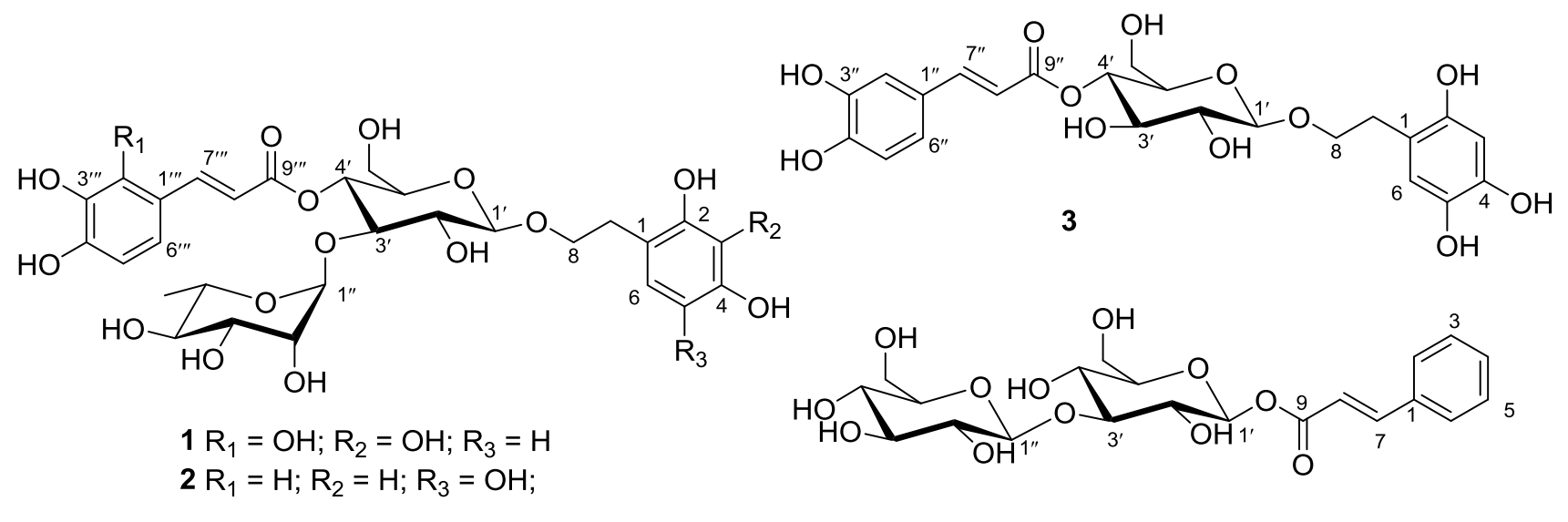

4

\section{Results and Discussion}

Marinoid J (1), a yellow oil, has a molecular formula identified as $\mathrm{C}_{29} \mathrm{H}_{36} \mathrm{O}_{17}$ based on the NMR and HRESIMS data $\left([\mathrm{M}+\mathrm{H}]^{+}, m / z: 657.2029\right.$; calcd. for $\mathrm{C}_{29} \mathrm{H}_{37} \mathrm{O}_{17} \mathrm{~m} / z$ : 657.2031). The ${ }^{1} \mathrm{H},{ }^{13} \mathrm{C}$ NMR (Table 1), COSY and HMQC spectra of 1 showed the presence of two AB system signals at $\delta_{\mathrm{H}} 6.71$ $(1 \mathrm{H}, \mathrm{d}, J=8.7 \mathrm{~Hz}, \mathrm{H}-5)$ and $7.07(1 \mathrm{H}, \mathrm{d}, J=8.7 \mathrm{~Hz}, \mathrm{H}-6)$ for the 2,3,4-trihydroxyphenyl moiety; and $\delta_{\mathrm{H}} 6.82\left(1 \mathrm{H}, \mathrm{d}, J=8.7 \mathrm{~Hz}, \mathrm{H}-5^{\prime \prime \prime}\right)$ and $7.48\left(1 \mathrm{H}, \mathrm{d}, J=8.7 \mathrm{~Hz}, \mathrm{H}-6^{\prime \prime \prime}\right)$ for the 2,3,4-trihydroxycinnamoy moiety, two trans-olefinic protons as AB-type signals at $\delta_{\mathrm{H}} 6.35\left(1 \mathrm{H}, \mathrm{d}, J=15.9 \mathrm{~Hz}, \mathrm{H}-8^{\prime \prime \prime}\right)$ and 7.67 $\left(1 \mathrm{H}, \mathrm{d}, J=15.9 \mathrm{~Hz}, \mathrm{H}-7^{\prime \prime \prime}\right)$. In addition, two anomeric signals at $\delta_{\mathrm{H}} 4.38\left(1 \mathrm{H}, \mathrm{d}, J=7.9 \mathrm{~Hz}, \mathrm{H}-1^{\prime}\right) /$ $\delta_{\mathrm{C}} 104.2$ and $\delta_{\mathrm{H}} 5.19\left(1 \mathrm{H}, \mathrm{d}, J=1.6 \mathrm{~Hz}, \mathrm{H}-1^{\prime \prime}\right) / \delta_{\mathrm{C}} 103.0$, which were identified as $\beta$-D-glucopyranose and $\alpha$-L-rhamnopyranose, respectively, glucose and rhamnose in $\mathbf{1}$, were verified by TLC analysis after acid hydrolysis [2]. This above analytical data, combined with the NMR data, suggested that $\mathbf{1}$ is a phenylethyl glycoside [3]. The HMBC spectrum of 1 showed the key correlations between $\mathrm{H}-4^{\prime}$ and C-9'", between $\mathrm{H}-3^{\prime}$ and $\mathrm{C}-1^{\prime \prime}$ and between $\mathrm{H}-1^{\prime}$ and $\mathrm{C}-8$, which suggested that the linkages of $\mathrm{C}-1^{\prime}$, C-3' and C-4' of glucose were directly connected to C-8 of the phenylethanol moiety, C-1" of rhamnose and C-9"' of the $2^{\prime \prime \prime}, 3^{\prime \prime \prime}, 4^{\prime \prime \prime}-$ trihydroxycinnamoyl moiety, respectively (Figure 2). Thus, the structure of 1 was elucidated as 1'-O-2,3,4-trihydroxy-phenylethoxy- $O$ - $\alpha$-L-rhamnopyranosyl-( $\left.1^{\prime \prime} \rightarrow 3^{\prime}\right)$ (4'-O-2"', $3^{\prime \prime \prime}, 4^{\prime \prime \prime}-$ trihydroxycinnamoy)- $\beta$-D-glucopyranoside and amed marinoid J. 
Table 1. ${ }^{1} \mathrm{H}$ and ${ }^{13} \mathrm{C}$ NMR data of $\mathbf{1}$ and $\mathbf{2}^{\mathrm{a}}$.

\begin{tabular}{|c|c|c|c|c|c|}
\hline & \multirow{2}{*}{ Position } & \multicolumn{2}{|r|}{1} & \multicolumn{2}{|r|}{2} \\
\hline & & $\delta_{C}$, Mult & $\delta_{\mathrm{H}}(J$ in $\mathrm{Hz})$ & $\delta_{\mathrm{C}}$, Mult & $\delta_{\mathrm{H}}(J$ in $\mathrm{Hz})$ \\
\hline \multirow{9}{*}{ phenylethyl } & 1 & $115.9, \mathrm{C}$ & & $121.4, \mathrm{C}$ & \\
\hline & 2 & $147.6, \mathrm{C}$ & & $148.6, \mathrm{C}$ & \\
\hline & 3 & $130.6, \mathrm{C}$ & & $103.9, \mathrm{CH}$ & $6.16(\mathrm{~s})$ \\
\hline & 4 & $156.8, \mathrm{C}$ & & 143.7, C & \\
\hline & 5 & $116.0, \mathrm{CH}$ & $6.71(\mathrm{~d}, 8.7)$ & $143.5, \mathrm{C}$ & \\
\hline & 6 & 131.0, $\mathrm{CH}$ & $7.07(\mathrm{~d}, 8.7)$ & $110.1, \mathrm{CH}$ & $6.41(\mathrm{~s})$ \\
\hline & 7 & $36.3, \mathrm{CH}_{2}$ & $2.81-2.84(\mathrm{~m})$ & $34.6, \mathrm{CH}_{2}$ & $2.83-2.87(\mathrm{~m})$ \\
\hline & 8 & $72.3, \mathrm{CH}_{2}$ & $4.02-4.06(\mathrm{~m})$ & $72.3, \mathrm{CH}_{2}$ & $4.00-4.04(\mathrm{~m})$ \\
\hline & & & $3.70-3.74(\mathrm{~m})$ & & $3.71-3.75(\mathrm{~m})$ \\
\hline \multirow{7}{*}{ glucosyl } & $1^{\prime}$ & $104.2, \mathrm{CH}$ & $4.38(\mathrm{~d}, 7.9)$ & $103.5, \mathrm{CH}$ & $4.78(\mathrm{~d}, 7.3)$ \\
\hline & $2^{\prime}$ & $76.2, \mathrm{CH}$ & $3.38(\mathrm{dd}, 9.1,7.9)$ & $74.5, \mathrm{CH}$ & $3.40(\mathrm{dd}, 9.1,7.3)$ \\
\hline & $3^{\prime}$ & $81.3, \mathrm{CH}$ & $3.81(t, 9.1)$ & $81.1, \mathrm{CH}$ & $3.84(t, 9.1)$ \\
\hline & $4^{\prime}$ & $70.6, \mathrm{CH}$ & $4.91(t, 9.1)$ & $70.5, \mathrm{CH}$ & $4.94(t, 9.1)$ \\
\hline & $5^{\prime}$ & $76.0, \mathrm{CH}$ & $3.52-3.57(\mathrm{~m})$ & $76.1, \mathrm{CH}$ & $3.50-3.55(\mathrm{~m})$ \\
\hline & $6^{\prime}$ & $62.3, \mathrm{CH}_{2}$ & $3.58-3.63(\mathrm{~m})$ & $60.3, \mathrm{CH}_{2}$ & $3.61-3.65(\mathrm{~m})$ \\
\hline & & & $3.49-3.54(\mathrm{~m})$ & & $3.52-3.56(\mathrm{~m})$ \\
\hline \multirow{6}{*}{ rhamnosyl } & $1 "$ & $103.0, \mathrm{CH}$ & $5.19(\mathrm{~d}, 1.6)$ & $102.0, \mathrm{CH}$ & $4.58(\mathrm{~d}, 1.6)$ \\
\hline & $2^{\prime \prime}$ & $72.0, \mathrm{CH}$ & $3.91(\mathrm{dd}, 3.5,1.6)$ & $72.1, \mathrm{CH}$ & $3.92(\mathrm{dd}, 3.1,1.2)$ \\
\hline & $3 "$ & $72.2, \mathrm{CH}$ & $3.56(\mathrm{dd} ; 9.5,3.5)$ & $72.3, \mathrm{CH}$ & $3.58(\mathrm{dd} ; 9.7,3.1)$ \\
\hline & $4^{\prime \prime}$ & $73.8, \mathrm{CH}$ & $3.28(t, 9.5)$ & $73.5, \mathrm{CH}$ & $3.25(t, 9.7)$ \\
\hline & $5^{\prime \prime}$ & $70.4, \mathrm{CH}$ & $3.54-3.58(\mathrm{~m})$ & $70.6, \mathrm{CH}$ & $3.55-3.59(\mathrm{~m})$ \\
\hline & $6^{\prime \prime}$ & $18.4, \mathrm{CH}_{3}$ & $1.08(\mathrm{~d}, 6.2)$ & $18.2, \mathrm{CH}_{3}$ & $1.05(\mathrm{~d}, 6.2)$ \\
\hline cinnamoyl in $\mathbf{1}$ & $1^{\prime \prime \prime}$ & $127.8, \mathrm{C}$ & & $127.7, \mathrm{C}$ & \\
\hline \multirow{8}{*}{ caffeoyl in 2} & $2^{\prime \prime \prime}$ & $147.5, \mathrm{C}$ & & $115.3, \mathrm{CH}$ & $7.00(\mathrm{~d}, 1.5)$ \\
\hline & $3^{\prime \prime \prime}$ & $133.4, \mathrm{C}$ & & 143.6, C & \\
\hline & $4^{\prime \prime \prime}$ & $161.5, \mathrm{C}$ & & 145.6, C & \\
\hline & $5^{\prime \prime \prime}$ & $117.7, \mathrm{CH}$ & $6.82(\mathrm{~d}, 8.7)$ & $119.5, \mathrm{CH}$ & $6.94(\mathrm{~d}, 6.5)$ \\
\hline & $6^{\prime \prime \prime}$ & $130.9, \mathrm{CH}$ & $7.48(\mathrm{~d}, 8.7)$ & $123.2, \mathrm{CH}$ & $6.60(\mathrm{dd}, 6.5,1.5)$ \\
\hline & $7^{\prime \prime \prime}$ & $147.8, \mathrm{CH}$ & $7.67(\mathrm{~d}, 15.9)$ & $144.5, \mathrm{CH}$ & $7.46(\mathrm{~d}, 15.8)$ \\
\hline & $8^{\prime \prime \prime}$ & $115.6, \mathrm{CH}$ & $6.35(\mathrm{~d}, 15.9)$ & $115.3, \mathrm{CH}$ & $6.39(\mathrm{~d}, 15.8)$ \\
\hline & $9^{\prime \prime \prime}$ & $168.3, \mathrm{C}$ & & $169.2, \mathrm{C}$ & \\
\hline
\end{tabular}

Marinoid K (2), a yellow oil, has a molecular formula that was elucidated as $\mathrm{C}_{29} \mathrm{H}_{36} \mathrm{O}_{16}$ with the aid of the NMR and HR-ESI-MS data $\left([\mathrm{M}+\mathrm{Na}]^{+}, m / z\right.$ : 663.1898; calcd. for $\mathrm{C}_{29} \mathrm{H}_{36} \mathrm{O}_{16} \mathrm{Na} m / z$ : 663.1901). The ${ }^{1} \mathrm{H},{ }^{13} \mathrm{C}$ NMR (Table 1), COSY and HMQC spectra of 2 indicated that the presence of proton signals at $\delta_{\mathrm{H}} 6.16(1 \mathrm{H}, \mathrm{s}, \mathrm{H}-3)$ and $6.41(1 \mathrm{H}, \mathrm{s}, \mathrm{H}-6)$ for the 2,4,5-trihydroxyphenyl moiety; and three proton signals at $\delta_{\mathrm{H}} 7.00\left(1 \mathrm{H}, \mathrm{d}, J=1.5 \mathrm{~Hz}, \mathrm{H}-2^{\prime \prime \prime}\right), 6.94\left(1 \mathrm{H}, \mathrm{d}, J=6.5 \mathrm{~Hz}, \mathrm{H}-5^{\prime \prime \prime}\right)$ and $6.60(1 \mathrm{H}, \mathrm{dd}$, $\left.J=6.5,1.5 \mathrm{~Hz}, \mathrm{H}-6^{\prime \prime \prime}\right)$ for the caffeoyl moiety, two trans-olefinic protons as AB-type signals at $\delta_{\mathrm{H}} 6.39$ $\left(1 \mathrm{H}, \mathrm{d}, J=15.8 \mathrm{~Hz}, \mathrm{H}-8^{\prime \prime \prime}\right)$ and $7.46\left(1 \mathrm{H}, \mathrm{d}, J=15.8 \mathrm{~Hz}, \mathrm{H}-7^{\prime \prime \prime}\right)$. In addition, two anomeric signals at $\delta_{\mathrm{H}}$ $4.78\left(1 \mathrm{H}, \mathrm{d}, J=7.3 \mathrm{~Hz}, \mathrm{H}-1^{\prime}\right) / \delta_{\mathrm{C}} 103.5$ and $\delta_{\mathrm{H}} 4.58\left(1 \mathrm{H}, \mathrm{d}, J=1.6 \mathrm{~Hz}, \mathrm{H}-1^{\prime \prime}\right) / \delta_{\mathrm{C}} 102.0$, which were identified as $\beta$-D-glucopyranose and $\alpha$-L-rhamnopyranose, glucose and rhamnose in $\mathbf{2}$, were verified by 
TLC analysis after acid hydrolysis. From these above analytical data, combined with the NMR data, we proposed that 2, like $\mathbf{1}$, is a phenylethyl glycoside [3]. The linkages of C-1', C-3' and C-4' of glucose were directly connected to $\mathrm{C}-8$ of the phenylethanol moiety, $\mathrm{C}-1^{\prime \prime}$ of rhamnose and C-9"' of the caffeoyl moiety, respectively, which was further confirmed by the key HMBC correlations between H-4' and C-9'", between H-3' and C-1" and between H-1' and C-8 (Figure 2). The structure of 2 was thus elucidated to be $1^{\prime}-O-2,4,5$-trihydroxy-phenylethoxy- $O$ - $\alpha$-L-rhamnopyranosyl- $\left(1^{\prime \prime} \rightarrow 3^{\prime}\right)-\left(4^{\prime}-O\right.$ caffeoyl)- $\beta$-D-glucopyranoside and named marinoid K.

Figure 2. Selected ${ }^{1} \mathrm{H}-{ }^{1} \mathrm{H}$ COSY and HMBC correlations of $\mathbf{1}-\mathbf{4}$.

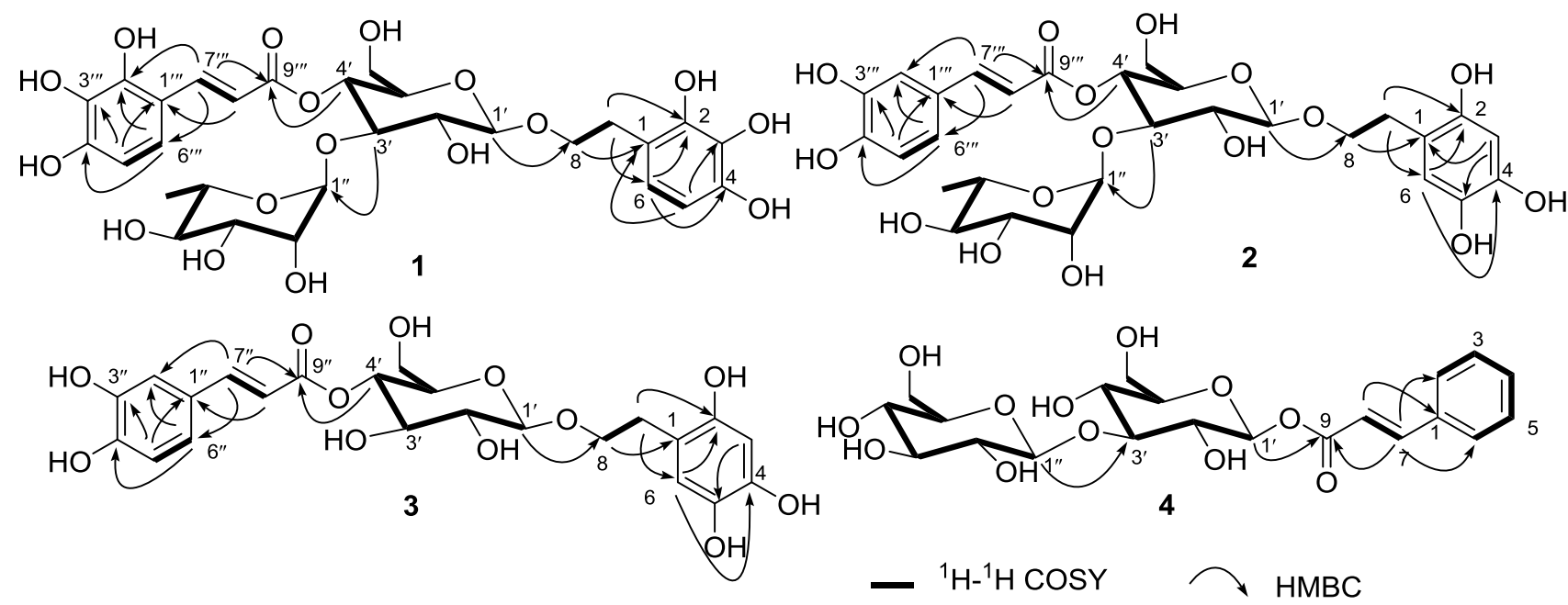

Marinoid L (3), a yellow oil, has a molecular formula that was determined to be $\mathrm{C}_{23} \mathrm{H}_{26} \mathrm{O}_{12}$ by HRESIMS (found $[\mathrm{M}+\mathrm{H}]^{+}$at $m / z$ 495.1501, calcd. for $[\mathrm{M}+\mathrm{H}]^{+}, 495.1503$ ), as well as ${ }^{1} \mathrm{H}$ and ${ }^{13} \mathrm{C}$ data (Table 2). The ${ }^{1} \mathrm{H},{ }^{13} \mathrm{C}$ NMR, COSY and HMQC spectra of 3 displayed proton signals at $\delta_{\mathrm{H}} 6.61$ $(1 \mathrm{H}, \mathrm{s}, \mathrm{H}-3)$ and $6.64(1 \mathrm{H}, \mathrm{s}, \mathrm{H}-6)$ for the 2,4,5-trihydroxyphenyl moiety; and three proton signals at $\delta_{\mathrm{H}}$ $7.03\left(1 \mathrm{H}, \mathrm{d}, J=1.5 \mathrm{~Hz}, \mathrm{H}-2^{\prime \prime}\right), 7.01\left(1 \mathrm{H}, \mathrm{d}, J=7.5 \mathrm{~Hz}, \mathrm{H}-5^{\prime \prime}\right)$ and $6.67\left(1 \mathrm{H}, \mathrm{dd}, J=7.5,1.5 \mathrm{~Hz}, \mathrm{H}-6^{\prime \prime}\right)$ for the caffeoyl moiety, two trans-olefinic protons as AB-type signals at $\delta_{\mathrm{H}} 6.30(1 \mathrm{H}, \mathrm{d}, J=17.2 \mathrm{~Hz}$, $\left.\mathrm{H}-8^{\prime \prime}\right)$ and $7.56\left(1 \mathrm{H}, \mathrm{d}, J=17.2 \mathrm{~Hz}, \mathrm{H}-7^{\prime \prime}\right)$. NMR spectra also indicated the presence of a $\beta$-glucosyl group, i.e., one anomeric carbon resonance at $\delta_{\mathrm{C}} 103.1\left(\mathrm{C}-1^{\prime}\right)$ and one anomeric proton at $\delta_{\mathrm{H}} 4.34(1 \mathrm{H}$, $\mathrm{d}, J=7.5 \mathrm{~Hz}, \mathrm{H}-1^{\prime}$ ), which was identified as $\beta$-D-glucopyranose, glucose in $\mathbf{3}$, and verified by TLC analysis after acid hydrolysis. The ${ }^{1} \mathrm{H}$ and ${ }^{13} \mathrm{C}$ NMR spectra (Table 2) are similar to those of calceolarioside A, except for the extra hydroxyl group on the phenylethyl moiety 3 (3: 2,4,5-trihydroxyphenyl, while calceolarioside A: 3,4-dihydroxyphenyl) [4]. The gross structure was further established by the aid of COSY and HMBC experiments (Figure 2). The key HMBC correlations between $\mathrm{H}-4^{\prime}$ and C-9" and between $\mathrm{H}-1^{\prime}$ and $\mathrm{C}-8$ suggested that the linkages of $\mathrm{C}-1^{\prime}$ and $\mathrm{C}-4^{\prime}$ of glucose were directly connected to $\mathrm{C}-8$ of the phenylethyl moiety and C-9" of caffeoyl moiety, respectively (Figure 2). Thus, the structure of 3 was elucidated to be 1'-O-2,4,5-trihydroxy-phenylethoxy-(4'-O-caffeoyl)- $\beta$-D-gluco pyranoside and named marinoid L. 
Table 2. ${ }^{1} \mathrm{H}$ and ${ }^{13} \mathrm{C}$ NMR data of 3 and $4{ }^{\mathrm{a}}$.

\begin{tabular}{|c|c|c|c|c|c|}
\hline & \multirow{2}{*}{ Position } & \multicolumn{3}{|c|}{3} & \multirow{2}{*}{$\begin{array}{c}4 \\
\delta_{H}(J \text { in } \mathrm{Hz})\end{array}$} \\
\hline & & $\delta_{\mathrm{C}}$, Mult & $\delta_{\mathrm{H}}(J$ in $\mathrm{Hz})$ & $\delta_{\mathrm{C}}$, Mult & \\
\hline phenylethyl in $\mathbf{3}$ & 1 & $125.8, \mathrm{C}$ & & $134.3, \mathrm{C}$ & \\
\hline \multirow{9}{*}{ cinnamoyl in $\mathbf{4}$} & 2 & $155.2, \mathrm{C}$ & & $127.9, \mathrm{CH}$ & $7.60(\mathrm{~d}, 7.6)$ \\
\hline & 3 & $112.2, \mathrm{CH}$ & $6.61(\mathrm{~s})$ & $128.6, \mathrm{CH}$ & 7.40-7.45 (m, overlap) \\
\hline & 4 & $144.4, \mathrm{C}$ & & $130.1, \mathrm{CH}$ & 7.40-7.45 (m, overlap) \\
\hline & 5 & $144.2, \mathrm{C}$ & & $128.6, \mathrm{CH}$ & 7.40-7.45 (m, overlap) \\
\hline & 6 & $115.1, \mathrm{CH}$ & $6.64(\mathrm{~s})$ & $127.9, \mathrm{CH}$ & $7.60(\mathrm{~d}, 7.6)$ \\
\hline & 7 & $35.1, \mathrm{CH}_{2}$ & $2.78-2.82(\mathrm{~m})$ & $145.1, \mathrm{CH}$ & $7.73(d, 15.6)$ \\
\hline & 8 & $60.8, \mathrm{CH}_{2}$ & $3.92-3.96(\mathrm{~m})$ & 117.3, $\mathrm{CH}$ & $6.59(\mathrm{~d}, 15.6)$ \\
\hline & & & $3.68-3.72(\mathrm{~m})$ & & \\
\hline & 9 & & & 166.7, C & \\
\hline \multirow{7}{*}{ glucosyl } & $1^{\prime}$ & $103.1, \mathrm{CH}$ & $4.34(\mathrm{~d}, 7.5)$ & $105.2, \mathrm{CH}$ & $4.28(\mathrm{~d}, 7.3)$ \\
\hline & $2^{\prime}$ & $74.0, \mathrm{CH}$ & $3.37(\mathrm{dd}, 9.1,7.5)$ & $74.6, \mathrm{CH}$ & $3.33(\mathrm{dd}, 9.1,7.3)$ \\
\hline & $3^{\prime}$ & $76.5, \mathrm{CH}$ & $3.81(\mathrm{t}, 9.1)$ & $82.4, \mathrm{CH}$ & $4.09(\mathrm{t}, 9.1)$ \\
\hline & $4^{\prime}$ & $70.3, \mathrm{CH}$ & $4.91(t, 9.1)$ & $70.6, \mathrm{CH}$ & $4.51(t, 9.1)$ \\
\hline & $5^{\prime}$ & 73.6, $\mathrm{CH}$ & $3.54-3.57(\mathrm{~m})$ & $73.1, \mathrm{CH}$ & $3.76-3.80(\mathrm{~m})$ \\
\hline & $6^{\prime}$ & $63.2, \mathrm{CH}_{2}$ & $3.58-3.63(\mathrm{~m})$ & $63.8, \mathrm{CH}_{2}$ & $3.70-3.74(\mathrm{~m})$ \\
\hline & & & $3.49-3.54(\mathrm{~m})$ & & $3.54-3.59(\mathrm{~m})$ \\
\hline caffeoyl in $\mathbf{3}$ & $1^{\prime \prime}$ & $129.1, \mathrm{C}$ & & $104.1, \mathrm{CH}$ & $4.41(\mathrm{~d}, 7.6)$ \\
\hline \multirow{9}{*}{ glucosyl in $\mathbf{4}$} & $2^{\prime \prime}$ & $114.7, \mathrm{CH}$ & $7.03(\mathrm{~d}, 1.5)$ & $73.1, \mathrm{CH}$ & $3.29(\mathrm{dd}, 9.1,7.6)$ \\
\hline & $3 "$ & $145.1, \mathrm{C}$ & & $77.7, \mathrm{CH}$ & $4.02(t, 9.1)$ \\
\hline & $4^{\prime \prime}$ & $147.8, \mathrm{C}$ & & $70.4, \mathrm{CH}$ & $4.49(\mathrm{t}, 9.1)$ \\
\hline & $5^{\prime \prime}$ & $115.1, \mathrm{CH}$ & $7.01(\mathrm{~d}, 7.5)$ & $71.7, \mathrm{CH}$ & $3.72-3.76(\mathrm{~m})$ \\
\hline & $6^{\prime \prime}$ & $121.7, \mathrm{CH}$ & $6.67(\mathrm{dd}, 7.5,1.5)$ & $62.7, \mathrm{CH}_{2}$ & $3.69-3.72(\mathrm{~m})$ \\
\hline & & & & & $3.55-3.59(\mathrm{~m})$ \\
\hline & $7 "$ & 145.6, CH & $7.56(\mathrm{~d}, 17.2)$ & & \\
\hline & $8^{\prime \prime}$ & $114.7, \mathrm{CH}$ & $6.30(\mathrm{~d}, 17.2)$ & & \\
\hline & $9^{\prime \prime}$ & 167.7, C & & & \\
\hline
\end{tabular}

Marinoid M (4), a yellowish oil, has a molecular formula identified as $\mathrm{C}_{21} \mathrm{H}_{28} \mathrm{O}_{12}$ from the HREIMS for the peak at $m / z 495.1475[\mathrm{M}+\mathrm{Na}]^{+}$(calcd. for $\mathrm{C}_{21} \mathrm{H}_{28} \mathrm{O}_{12} \mathrm{Na}, 495.1473$ ) and the NMR data. The ${ }^{1} \mathrm{H},{ }^{13} \mathrm{C}$ NMR (Table 2), COSY and HMQC spectra of 4 showed signals at $\delta_{\mathrm{H}} 7.60(2 \mathrm{H}, \mathrm{d}, J=7.6$, $\mathrm{H}-2 / \mathrm{H}-6)$ and 7.40-7.45 (3H, m, H-3/H-4/H-5), which showed that the phenyl moiety in compound 4 is not substituted; in addition to two trans-olefinic protons as AB-type signals at $\delta_{\mathrm{H}} 6.59(1 \mathrm{H}, \mathrm{d}$, $J=15.6 \mathrm{~Hz}, \mathrm{H}-8)$ and $7.73(1 \mathrm{H}, \mathrm{d}, J=15.6 \mathrm{~Hz}, \mathrm{H}-7)$. NMR spectra also indicated the presence of two $\beta$-glucosyl groups by two anomeric protons at $\delta_{\mathrm{H}} 4.41\left(1 \mathrm{H}, \mathrm{d}, J=7.6 \mathrm{~Hz}, \mathrm{H}-1^{\prime \prime}\right)$ and $4.28(1 \mathrm{H}, \mathrm{d}$, $\left.J=7.3 \mathrm{~Hz}, \mathrm{H}-1^{\prime}\right)$ and two anomeric carbon resonances at $\delta_{\mathrm{C}} 104.1$ (C-1") and $105.2\left(\mathrm{C}-1^{\prime}\right)$, which were further confirmed by TLC analysis after acid hydrolysis. The gross structure was further established by the aid of COSY and HMBC experiments (Figure 2). The HMBC spectrum of 4 showed key correlations between $\mathrm{H}-1^{\prime}$ and $\mathrm{C}-9$ and between $\mathrm{H}-3^{\prime}$ and $\mathrm{C}-1^{\prime \prime}$, which confirmed the linkages of C-3' and $\mathrm{C}-1^{\prime}$ of glucose directly connected to C-1" of glucose and C-9 of the cinnamoyl moiety, 
respectively (Figure 2). Thus, the structure of 4 was elucidated to be $\beta$-D-glucosyl- $\left(1^{\prime \prime} \rightarrow 3^{\prime}\right)-\left(1^{\prime}-O\right.$ cinnamoyl)- $\beta$-D-glucopyranoside and named marinoid $\mathrm{M}$.

The cellular antioxidant activities of compounds 1-4 were measured using the cellular antioxidant assay (CAA) assay. The $\mathrm{EC}_{50}$ values of compounds $\mathbf{1}-\mathbf{4}$ were $23.0 \pm 0.71 \mu \mathrm{M}, 36.2 \pm 1.83 \mu \mathrm{M}$, $114.5 \pm 0.40 \mu \mathrm{M}$ and $247.8 \pm 2.47 \mu \mathrm{M}$, respectively, of the same order of the positive control quercetin $\left(\mathrm{EC}_{50}=11.0 \pm 0.18 \mu \mathrm{M}\right)$.

\section{Experimental Section}

\subsection{General Experimental Procedures}

UV spectra were recorded in $\mathrm{MeOH}$ on a Perkin-Elmer Lambda $35 \mathrm{UV}-\mathrm{V}$ is spectrophotometer (Wellesley, MA, USA). The IR spectra were measured in $\mathrm{KBr}$ on a WQF-410 FT-IR spectrophotometer (Beifen-Ruili, Beijing, China). NMR spectra were recorded on a Bruker AV 600 MHz NMR spectrometer with TMS as an internal standard (Bruker, Bremen, Germany). HRESIMS data were obtained from Bruker Maxis mass spectrometer (Bruker, Bremen, Germany). A Waters-2695 HPLC system, using a Sunfire ${ }^{\mathrm{TM}} \mathrm{C}_{18}$ column $(150 \times 10 \mathrm{~mm}$ i.d., $10 \mu \mathrm{m}$, Waters, Milford, MA, USA) coupled to a Waters 2998 photodiode array detector (Waters, Milford, MA, USA) was used. Optical rotation data were measured by a Perkin-Elmer Model 341 polarimeter (Wellesley, MA, USA). The silica gel $\mathrm{GF}_{254}$ used for TLC was supplied by the Qingdao Marine Chemical Factory, Qingdao, China. Spots were detected on TLC under UV light or by heating after spraying with 5\% $\mathrm{H}_{2} \mathrm{SO}_{4}$ in EtOH. All solvent ratios are measured v/v.

\subsection{Plant Material}

The fruits of A. marina were collected from Beihai City, Guangxi, China, in September 2011. The specimen was identified by Hangqing Fan from Guangxi Mangrove Research Center, Guangxi Academy of Sciences. A voucher specimen (2011-GXAS-008) was deposited in Guangxi Key Laboratory of Marine Environmental Science, Guangxi Academy of Sciences, China.

\subsection{Extraction and Isolation}

The fruits of $A$. marina $(35.4 \mathrm{~kg}$ ) were exhaustively extracted in a large metal bowl (diameter $80 \mathrm{~cm}$, volume $50 \mathrm{~L})$ with $\mathrm{EtOH}-\mathrm{CH}_{2} \mathrm{Cl}_{2}(2: 1,3 \times 30 \mathrm{~L})$ at $25^{\circ} \mathrm{C}$ for $3 \times 4$ days. The solvent was evaporated in vacuo to afford a syrupy residue $(935 \mathrm{~g})$ that was suspended in distilled water $(1.5 \mathrm{~L})$ and fractionated successively with petroleum ether $(3 \times 2 \mathrm{~L})$, ethyl acetate $(3 \times 2 \mathrm{~L})$ and $n$-butanol $(3 \times 2 \mathrm{~L})$. The ethyl acetate soluble portion (165 g) was subjected to column chromatography on silica gel, using $\mathrm{CHCl}_{3}-\mathrm{Me}_{2} \mathrm{CO}$ (from 10:0 to 0:10) as the eluent, giving eleven fractions (A-M). Fraction L was subjected to column chromatography to afford ten sub-fractions (L1-L10). Sub-fraction L3 was subjected to Sephadex LH-20 column chromatography with $\mathrm{CHCl}_{3}-\mathrm{MeOH}(1: 1)$, then separated by HPLC, using the mixtures of $\mathrm{MeOH}-\mathrm{H}_{2} \mathrm{O}$ (45:55) to yield 1 (2.5 mg). Sub-fraction L4 was separated by HPLC, using the mixtures of $\mathrm{MeOH}-\mathrm{H}_{2} \mathrm{O}$ (from 5:95 to 60:40) to yield 3 (4.0 mg) and 2 (3.1 mg), respectively. Fraction D was further subjected to column chromatography to afford four sub-fractions 
(D1-D4); sub-fraction D4 was separated by HPLC, using mixtures of $\mathrm{MeOH}-\mathrm{H}_{2} \mathrm{O}$ (5:95) to yield $4(2.2 \mathrm{mg})$.

Marinoid J (1): Yellow oil; $[\alpha]_{\mathrm{D}}^{20}-24.7^{\circ}\left(c\right.$ 0.74, MeOH); UV (MeOH) $\lambda_{\max }(\log \varepsilon) \mathrm{nm}: 214$ (4.12), 246 (4.00), 291 (4.12), 331 (3.75); IR (KBr) $v_{\max }$ 3381, 1691, 1621 and $1602 \mathrm{~cm}^{-1}$; ${ }^{1} \mathrm{H}\left(\mathrm{CD}_{3} \mathrm{OD}\right.$, $600 \mathrm{MHz}$ ) and ${ }^{13} \mathrm{C}\left(\mathrm{CD}_{3} \mathrm{OD}, 150 \mathrm{MHz}\right) \mathrm{NMR}$; see Table 1; HRESIMS $\mathrm{m} / z 657.2029$ (calcd. for $\left.\mathrm{C}_{29} \mathrm{H}_{36} \mathrm{O}_{17}+\mathrm{H}, 657.2031\right)$.

Marinoid K (2): Yellow oil; $[\alpha]_{\mathrm{D}}^{20}-35.5^{\circ}(c 0.39, \mathrm{MeOH})$; UV (MeOH) $\lambda_{\max }(\log \varepsilon) \mathrm{nm}: 215$ (3.75), 241 (3.97), 289 (4.01), 332 (3.67); IR (KBr) $v_{\max }$ 3386, 1693, 1622 and $1600 \mathrm{~cm}^{-1}$; ${ }^{1} \mathrm{H}\left(\mathrm{CD}_{3} \mathrm{OD}\right.$, $600 \mathrm{MHz}$ ) and ${ }^{13} \mathrm{C}\left(\mathrm{CD}_{3} \mathrm{OD}, 150 \mathrm{MHz}\right) \mathrm{NMR}$; see Table 1; HRESIMS: $m / z 663.1898$ (calcd. for $\left.\mathrm{C}_{29} \mathrm{H}_{36} \mathrm{O}_{16}+\mathrm{Na}, 663.1901\right)$.

Marinoid L (3): Yellow oil; $[\alpha]_{\mathrm{D}}^{20}-32.2^{\circ}\left(c\right.$ 0.46, MeOH); UV (MeOH) $\lambda_{\max }(\log \varepsilon) \mathrm{nm}: 214$ (4.09), 245 (4.01), 290 (4.12), 332 (3.23); IR (KBr) v $v_{\max }$ 3392, 1693, 1624 and $1600 \mathrm{~cm}^{-1}$; ${ }^{1} \mathrm{H}\left(\mathrm{CD}_{3} \mathrm{OD}\right.$, $600 \mathrm{MHz})$ and ${ }^{13} \mathrm{C}\left(\mathrm{CD}_{3} \mathrm{OD}, 150 \mathrm{MHz}\right) \mathrm{NMR}$; see Table 2; HRESIMS: $\mathrm{m} / z$ 495.1501 (calcd. for $\left.\mathrm{C}_{23} \mathrm{H}_{26} \mathrm{O}_{12}+\mathrm{H}, 495.1503\right)$.

Marinoid M (4): Yellow oil; $[\alpha]_{\mathrm{D}}^{20}+13.2^{\circ}(c 0.57, \mathrm{MeOH}) ; \mathrm{UV}(\mathrm{MeOH}) \lambda_{\max }(\log \varepsilon) \mathrm{nm}: 211$ (3.98), 245 (3.91), 289 (4.10); IR (KBr) $v_{\max } 3402,1690,1620$ and $1602 \mathrm{~cm}^{-1} ;{ }^{1} \mathrm{H}\left(\mathrm{CD}_{3} \mathrm{OD}, 600 \mathrm{MHz}\right)$ and ${ }^{13} \mathrm{C} \quad\left(\mathrm{CD}_{3} \mathrm{OD}, 150 \mathrm{MHz}\right) \quad \mathrm{NMR}$; see Table 2; HRESIMS: $m / z \quad 495.1475$ (calcd. for $\left.\mathrm{C}_{21} \mathrm{H}_{28} \mathrm{O}_{12}+\mathrm{Na}, 495.1473\right)$.

\subsection{Acid Hydrolysis of $\mathbf{1}-\mathbf{4}$}

Acid hydrolysis of 1-4 was carried out according to the reported method [2].

\subsection{Cellular Antioxidant Assay}

The cellular antioxidant activity (CAA) was carried out following the literature method [5].

\section{Conclusions}

Three new phenylethyl glycosides and a new cinnamoyl glycoside were isolated from the fruits of mangrove A. marina and identified. The CAA is a new approach to quantify antioxidant activity under physiological conditions when compared to chemical antioxidant activity assays [5]. The CAA assay has only recently been used in the marine natural product field [1]. Using this assay, compounds $\mathbf{2}$ and $\mathbf{3}$ showed relevant antioxidant activity comparable to the control, quercetin.

\section{Acknowledgments}

This study was supported by grants from National Natural Science Foundation of China (Nos. 31100260 and 81260480), Guangxi Key Laboratory of Marine Environmental Science and the Guangxi Academy of Sciences (GXKLHY13-06), Key Project of Science and Technology Department of Guangxi (14123001-7), the Knowledge Innovation Program of the Chinese Academy of Sciences (KSCX2-EW-J-28), the Natural Science Foundation of Guangxi (2012GXNSFAA053160), the Foundation of Key Laboratory of Plant Resources Conservation and Sustainable Utilization, South 
China Botanical Garden, Chinese Academy of Sciences (No. 201210ZS). Ri-Ming Huang acknowledges a CAS Academic Visitor Fellowship and thanks Ian S. Blagbrough, University of Bath, for many helpful discussions.

\section{Author Contributions}

In this paper, Cheng-Hai Gao was in charge of writing the manuscript. Zhi-Wei Su and Ming-Ben $\mathrm{Xu}$ were responsible for the isolation of the compounds. Yin-Ning Chen was responsible for structure identification. Xiang-Xi Yi and Wen-Pei Xie were in charge of biological activity. Lian $\mathrm{Yu}$ was responsible for the analysis of the data of biological activity, and Ri-Ming Huang is the corresponding author who was responsible for writing, arranging, checking and revising the manuscript.

\section{Conflicts of Interest}

The authors declare no conflict of interest.

\section{References}

1. Yi, X.X.; Chen, Y.; Xie, W.P.; Xu, M.B.; Chen, Y.N.; Gao, C.H.; Huang, R.M. Four new jacaranone analogs from the fruits of a Beibu Gulf mangrove Avicennia marina. Mar. Drugs 2014, 12, 2515-2525.

2. Tanaka, T.; Ikeda, T.; Kaku, N.; Zhu, X.H.; Okawa, M.; Yokomizo, K.; Uyeda, M.; Nohara, T. A new lignan glycoside and phenylethanoid glycosides from Strobilanthes cusia BREMEK. Chem. Pharm. Bull. 2004, 52, 1242-1245.

3. Ono, M.; Yoshida, A.; Ito, Y.; Nohara, T. Phenethyl alcohol glycosides and isopentenol glycoside from fruit of Bupleurum falcatum. Phytochemistry 1999, 51, 819-823.

4. Matsumoto, M.; Koga, S.; Shoyama, Y.; Nishioka, I. Phenolic glycoside composition of leaves and callus-cultures of Digitalis purpurea. Phytochemistry 1987, 26, 3225-3227.

5. Faller, A.L.K.; Fialho, E.; Liu, R.H. Cellular antioxidant activity of Feijoada whole meal coupled with an in vitro digestion. J. Agric. Food Chem. 2012, 60, 4826-4832.

(C) 2014 by the authors; licensee MDPI, Basel, Switzerland. This article is an open access article distributed under the terms and conditions of the Creative Commons Attribution license (http://creativecommons.org/licenses/by/3.0/). 